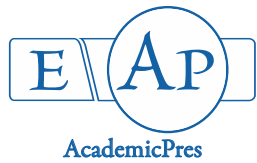

\title{
Effect of Whole Quail (Coturnix japonica) Egg Consumption on some Reproductive Parameters and Lipid Profile of Male Albino Rat (Rattus norvegicus)
}

\section{Chidozie N. OKOYE ${ }^{1}$, Samuel O. EKERE ${ }^{1}$, Onyinyechukwu A. AGINA ${ }^{2 *}$, Ikechukwu J. UDEANI ${ }^{2}$, Chukwunonso K. EZEASOR ${ }^{2}$}

\author{
${ }^{1}$ University of Nigeria Nsukka, Faculty of Veterinary Medicine, Department of Veterinary Obstetrics and Reproductive Disease, Enugu State, \\ Nigeria; chidozie.okoye@unn.edu.ng; Samuel.ekere@unn.edu.ng \\ ${ }^{2}$ University of Nigeria Nsukka, Faculty of Veterinary Medicine, Department of Veterinary Pathology and Microbiology, Enugu State, \\ Nigeria; onyinye.noel@unn.edu.ng ( ${ }^{*}$ correspondingauthor); ikudeani@yahoo.com;chukwunonso.ezeasor@unn.edu.ng
}

\begin{abstract}
The present study evaluated the effect of whole egg consumption on the liver, testes, cauda epididymal sperm reserve and lipid profile of male rats. These evaluations were carried out on adult twenty (20) male albino rats, which were randomly selected into four groups of 5 rats each, designated groups A, B, C and D. Group A was the control group and received only equivalent volume of distilled water, while groups B, C and D received $0.25 \mathrm{mg} / \mathrm{kg}, 0.5 \mathrm{mg} / \mathrm{kg}$ and $1.0 \mathrm{mg} / \mathrm{kg}$ body weight of the quail egg respectively. Standard procedures were carried out in the tissue processing, cauda epididymal sperm reserve and in lipid profile determinations. On days 35 and 49, the mean serum total cholesterol value of group D was significantly lower than that of the control group. On day 35, the mean serum low density lipoprotein and high density lipoprotein (LDL and HDL cholesterol) values of all the treatment groups were significantly lower and higher than that of the control group, respectively. However, on days 49 and 63, the mean serum very low density lipoprotein (VLDL cholesterol) and triglyceride values of all the treatment groups were significantly higher than that of the control group. A significant increase in cadual epididymal sperm count (CESR) was recorded on day 63 at the mid and high doses. No obvious pathological lesions were observed in the histomorphology of the testes and liver when compared to the control. Therefore, whole quail egg consumption caused an increase in serum triglyceride and very low density lipoprotein concentration, and also improved fertility. In other words, prolonged consumption of quail egg should be done with caution as it may predispose one to cardiovascular disease.
\end{abstract}

Keywords: cardiovascular disease, fertility, lipid profile, quail egg, Rattus norvegicus, testis, spermatozoa

\section{Introduction}

Japanese quail (Coturnix japonica) is a migratory pheasant bird that belongs to the family Phasianidae (Awad et al., 2015). It was domesticated since the eleventh century (Campos et al., 2013) and introduced in Nigeria in 1992 (NVRI, 1994). Japanese quail egg consumption is becoming increasingly popular in Nigeria (Onyewuchi et al., 2013) and also in many Asian, European and American countries (Campos et al., 2013; Tunsaringkarn et al., 2013; Tolik et al., 2014). This increasing popularity is due to its acclaimed nutritional (Campos et al., 2013; Tolik et al., 2014) and health benefits which may underscore its ethnomedical use
(Tunsaringkarn et al., 2013). Quail egg is known to contain more nutrients, high protein value and lower fat content when compared to chicken eggs (Campos et al., 2013; Tunsaringkarn et al., 2013; Tolik et al., 2014). Avidin found in egg albumen causes an increase in cholesterol level by producing a deficiency in bioavailability of biotin (Kovacs-Nolan et al., 2005). Its cholesterol content is higher than that of chicken (Jalaludeen and Churchill 2006; Sinanoglou et al., 2011; Aziz et al., 2012) or about equal to that of chicken (Bragagnalo and Rodriguez-Amaya 2003; Tolik et al., 2014).

Consumption of a large number of eggs is considered a risk factor for cardiovascular diseases due to high blood cholesterol levels (Bragagnalo and Rodriguez-Amaya 2003). 
316

High blood cholesterol levels (hypercholesterolemia) could predispose to atherosclerosis, which could result in pathologies such as myocardial infarction, cerebral infarction, aortic aneurysm, chronic ischaemic heart disease and ischaemic encephalopathy (Ihedioha et al., 2013). These cardiovascular pathologies could predispose to impotentia couendi due to erectile dysfunction consequent upon impaired cardiac supply and impaired arterial blood flow to the male reproductive organ resulting in infertility. The types of blood cholesterol associated with increased risk of atherosclerosis are the low density lipoprotein cholesterol (LDL-c) and very low density lipoprotein cholesterol (VLDL-c). LDL-c and VLDL-c carry cholesterol to tissues, unlike high density lipoprotein cholesterol (HDL-c) that clears cholesterol from developing and existing atheromas and carries it to the hepatic tissue for excretion in bile (Ihedioha et al., 2013). Cholesterol is the precursor for sex hormones ( $\mathrm{Hu}$ et al., 2010), and Japanese quail egg is reported to contain sex hormones of which progesterone and testosterone are present in appreciable quantities (Tunsaringkarn et al., 2013). These hormones do not only affect the reproductive system and fertility, but are pleiotropic and do possess anabolic properties (Tunsaringkarn et al., 2013).

Quail egg is anecdotally used to enhance fertility yet there is a paucity of information in the available literature on the effect of quail egg consumption on the liver, fertility and reproduction. In the light of the increasing consumption of quail eggs and its ethnomedical use, especially to enhance fertility juxtaposed with the potential cardiovascular pathologies, this study evaluated the alterations in the serum lipid profile, cauda epididymal sperm reserves and histomorphology of the testis and liver of adult male albino rats following oral administration of varied doses of Japanese quail (Coturnix japonica) whole egg.

\section{Materials and Methods}

\section{Experimental animals}

A total of 20 adult male Sprague-Dawley albino rats were used for the study. The rats were procured from the Laboratory Animal House of the Department of Pathology and Microbiology, Faculty of Veterinary Medicine, University of Nigeria, Nsukka. They were allowed two weeks for acclimatization. The rats were kept in groups in stainless steel cages in the Experimental Animal House of the Department of Veterinary Obstetrics and Reproductive Diseases, Faculty of Veterinary Medicine, University of Nigeria, Nsukka under standard conditions (ambient temperature: $\approx 28^{\circ} \mathrm{C}$, approximately 12 hours natural day light, humidity 60-70\%). Commercial pelleted feed (Vital, GCOML, Nigeria) containing approximately $14.5 \%$ crude protein and 2,500 Kcal/kg metabolizable energy, and potable water were provided ad libitum. Freshly laid quail eggs used for the study were procured from a commercial quail farm in Nsukka, Enugu State, Nigeria.

\section{Experimental design}

The rats were randomly assigned to four treatment groups designated A, B, C and D of 5 rats each. Group A was the control group and received only equivalent volume of distilled water, while group B received $0.25 \mathrm{mg} / \mathrm{kg}$, group $\mathrm{C}$ received $0.5 \mathrm{mg} / \mathrm{kg}$ and group D received $1.0 \mathrm{mg} / \mathrm{kg}$ body weight of the quail egg respectively for the entire duration of the study. A homogenised mixture of the egg white and yolk of freshly laid Japanese quail egg was prepared each day of dosing. The rats were dosed every other day for 9 weeks with the aid of an orogastric gavage between 09.00-10.00 hours.

\section{Sample collection and analysis}

Blood samples were collected on days 7, 21, 35, 49 and 63 of dosing from the retrobulbar plexus following the procedure of Stone (1954) between 10- $11 \mathrm{am}$. Serum was harvested from the blood samples one hour after clotting and centrifuged at $10,000 \mathrm{~g}$ for 10 minutes. The serum samples were used immediately for the serum lipid profile determination following standard procedures using Quimica Clinica Applicada test kits (Quimica Clinica Applicada, Spain) and digital colorimeter (Labtech, India). Determination of serum cholesterol was done by cholesterol oxidase-peroxidase method (Allain et al., 1974), while serum high density lipoprotein-cholesterol (HDL-C) was done following the dextran sulphate-magnesium (II) method (Albers et al., 1978). Serum triglyceride was determined by the glycerol phosphate oxidase enzymatic method (Bucolo and David, 1973), while determination of serum very low density lipoprotein cholesterol (VLDL-C) was obtained by dividing the serum triglyceride by 5 (Friedewald et al., 1972). Determination of serum low density lipoprotein cholesterol (LDL-C) was calculated using the Friedewald formula (Friedewald et al., 1972; Warnick et al., 1990).

At the end of the study the rats were humanely sacrificed, the testes and liver were carefully resected. Cauda epididymal sperm reserves were determined using the haemocytometric method described by Amman and Almquist (1961). The testicular and liver samples were promptly fixed in Bouin's fluid. Further histological preparations were carried out as described by Igwebuike and Eze (2010), Haschek et al. (2009), and stained with hematoxylin and eosin for light microscopy. Photomicrographs were captured using a Moticam ${ }^{\circ}$ digital camera (Motic China Group Co., Ltd., Xiamen, China) including Motic Images Plus 2.0 software.

\section{Ethical approval}

The housing, handling and welfare of the rats used for the study were duly observed in accordance with the Ethics and Regulation Guiding the use of animals as approved by the University of Nigeria Senate committee on Medical and Research ethics, with approval number 09/57172.

\section{Data analysis}

Data generated were subjected to one-way analysis of variance (ANOVA) using SPSS 16. Data having different time points were subjected to repeated measures ANOVA. Variant means were separated by the least significant difference (LSD) method. Significance was accepted at a probability level of less than 0.05 . Results were presented as means \pm standard error $(\mathrm{SE})$. 


\section{Results}

There was no significant $(P>0.05)$ variation in the mean serum cholesterol concentration of all the treatment groups given graded doses of quail egg orally when compared to the control group on days 7 and 21 (Table 1). However, on days 35 and 49 the mean serum cholesterol concentration of only group $\mathrm{D}$ was significantly lower than that of the control group, but by the end of dosing on day 63 , there was no significant variation in the mean serum cholesterol concentration of all the treatment groups when compared to the control group (Table 1).

The mean serum LDL cholesterol concentration of only group D was significantly lower than that of the control group on day 7 of dosing; but by day 21 the mean serum LDL cholesterol concentration of groups $\mathrm{A}$ and $\mathrm{B}$ were significantly $(P<0.05)$ lower, whilst that of group $\mathrm{D}$ was significantly higher than that of the control group (Table 2). By day 35 of dosing, the mean serum LDL cholesterol concentration of all the treatment groups was significantly lower than that of the control group (Table 2). However, by day 49 of dosing there was no significant variation in the mean serum LDL cholesterol concentration of all the groups; but by the end of dosing on day 63, only that of group $\mathrm{C}$ was lower than that of the control group (Table 2).

On day 7, the mean serum HDL cholesterol concentration of all the treatment groups were lower than that of the control group, but by day 21 , the mean serum HDL cholesterol concentration of only group $\mathrm{D}$ was significantly lower than that of the control (Table 3 ). However, by day 35 the mean serum HDL cholesterol concentration of all the treatment groups was significantly higher than that of the control, but by day 49 of dosing, the mean serum HDL cholesterol concentration of only group $\mathrm{D}$ was lower than that of the control group (Table 3). By the end of dosing on day 69, there was no significant variation in the mean serum HDL cholesterol concentration of all the treatment groups when compared to that of the control (Table 3).

There was no significant variation in the mean serum vLDL cholesterol concentration of all the treatment groups when compared to that of the control group on day 7 of dosing; but on days 21 and 35, the mean serum vLDL cholesterol concentration of group $\mathrm{C}$ was higher, whilst that of group $\mathrm{D}$ was lower when compared to that of the control group (Table 4). However, on days 49 and 63 the mean serum VLDL cholesterol concentration of all the treatment groups was significantly higher than that of the control group (Table 4).

The mean serum triglyceride concentration of only group $\mathrm{D}$ was significantly lower than that of the control group on day 7 of dosing (Table 5). On days 21 and 35, the mean serum triglyceride concentration of group $\mathrm{C}$ was higher whilst that of group $\mathrm{D}$ was significantly lower than

Table 1. Mean serum total cholesterol concentration $(\mathrm{mg} / \mathrm{dl})$ of albino rats given graded doses of whole quail egg per kilogram body weight $( \pm$ SEM)

\begin{tabular}{|c|c|c|c|c|}
\hline \multirow[b]{2}{*}{ Days } & \multicolumn{4}{|c|}{ Means \pm SEM } \\
\hline & $\begin{array}{l}\text { Group A } \\
\text { (Control) }\end{array}$ & $\begin{array}{c}\text { Group B } \\
(0.25 \mathrm{mg} / \mathrm{kg})\end{array}$ & $\begin{array}{c}\text { Group C } \\
(0.5 \mathrm{mg} / \mathrm{kg})\end{array}$ & $\begin{array}{c}\text { Group D } \\
(1.0 \mathrm{mg} / \mathrm{kg})\end{array}$ \\
\hline 7 & $97.44 \pm 13.57^{\mathrm{a}}$ & $92.31 \pm 14.04^{\mathrm{a}}$ & $92.31 \pm 8.88^{a}$ & $103.85 \pm 3.85^{a}$ \\
\hline 21 & $96.43 \pm 3.57^{\mathrm{a}}$ & $100.00 \pm 0.00^{\mathrm{a}}$ & $95.24 \pm 12.60^{\mathrm{a}}$ & $103.57 \pm 3.58^{a}$ \\
\hline 35 & $104.76 \pm 4.76^{a}$ & $96.43 \pm 4.57^{\mathrm{a}}$ & $92.24 \pm 9.53^{\mathrm{ab}}$ & $85.71 \pm 5.83^{b}$ \\
\hline 49 & $90.48 \pm 9.52^{\mathrm{ab}}$ & $78.57 \pm 4.12^{b c}$ & $90.47 \pm 4.76^{a}$ & $71.43 \pm 5.83^{c}$ \\
\hline 63 & $71.43 \pm 14.29^{a}$ & $75.00 \pm 8.99^{a}$ & $71.43 \pm 5.83^{\mathrm{a}}$ & $92.86 \pm 22.21^{\mathrm{a}}$ \\
\hline
\end{tabular}

Table 2. Mean serum low density lipoprotein cholesterol concentration $(\mathrm{mg} / \mathrm{dl})$ of albino rats given graded doses of whole quail egg per kilogram body weight $( \pm$ SEM $)$

\begin{tabular}{|c|c|c|c|c|}
\hline \multirow[b]{2}{*}{ Days } & \multicolumn{4}{|c|}{ Means \pm SEM } \\
\hline & $\begin{array}{c}\text { Group A } \\
\text { (Control) }\end{array}$ & $\begin{array}{c}\text { Group B } \\
(0.25 \mathrm{mg} / \mathrm{kg})\end{array}$ & $\begin{array}{c}\text { Group C } \\
(0.5 \mathrm{mg} / \mathrm{kg})\end{array}$ & $\begin{array}{c}\text { Group D } \\
(1.0 \mathrm{mg} / \mathrm{kg})\end{array}$ \\
\hline 7 & $27.28 \pm 14.34^{\mathrm{a}}$ & $30.98 \pm 11.38^{\mathrm{a}}$ & $45.96 \pm 11.45^{\mathrm{ab}}$ & $60.83 \pm 4.96^{b}$ \\
\hline 21 & $51.67 \pm 0.00^{a}$ & $33.10 \pm 8.43^{b}$ & $25.24 \pm 14.56^{\mathrm{b}}$ & $56.08 \pm 0.60^{a}$ \\
\hline 35 & $65.79 \pm 6.29^{a}$ & $30.43 \pm 5.93^{b}$ & $25.29 \pm 13.59^{b}$ & $39.25 \pm 4.53^{b}$ \\
\hline 49 & $34.97 \pm 12.55^{\mathrm{a}}$ & $20.07 \pm 3.50^{a}$ & $20.47 \pm 6.17^{\mathrm{a}}$ & $19.10 \pm 5.92^{\mathrm{a}}$ \\
\hline 63 & $55.95 \pm 7.14^{\mathrm{a}}$ & $45.71 \pm 9.91^{\mathrm{ab}}$ & $38.81 \pm 8.06^{b}$ & $57.81 \pm 24.72^{\mathrm{ab}}$ \\
\hline
\end{tabular}

${ }^{\mathrm{bc}}$ superscripts across a row indicate significant difference between the means of the different groups $(\mathrm{p} \leq 0.05)$.

Table 3. Mean serum high density lipoprotein cholesterol concentration $(\mathrm{mg} / \mathrm{dl})$ of albino rats given graded doses of whole quail egg per kilogram body weight $( \pm$ SEM $)$

\begin{tabular}{|c|c|c|c|c|}
\hline \multirow{3}{*}{ Days } & \multicolumn{4}{|c|}{ Means \pm SE } \\
\hline & Group A & Group B & Group C & Group D \\
\hline & (Control) & $(0.25 \mathrm{mg} / \mathrm{kg})$ & $(0.5 \mathrm{mg} / \mathrm{kg})$ & $(1.0 \mathrm{mg} / \mathrm{kg}))$ \\
\hline 7 & $57.14 \pm 0.00^{\mathrm{a}}$ & $46.43 \pm 3.58^{b}$ & $28.57 \pm 0.00^{c}$ & $28.57 \pm 0.00^{c}$ \\
\hline 21 & $42.86 \pm 0.00^{\mathrm{a}}$ & $42.86 \pm 0.00^{\mathrm{a}}$ & $38.10 \pm 4.76^{\mathrm{ab}}$ & $35.72 \pm 4.13^{b}$ \\
\hline 35 & $25.64 \pm 5.13^{\mathrm{a}}$ & $50.00 \pm 3.85^{b}$ & $51.28 \pm 5.13^{\mathrm{b}}$ & $38.46 \pm 4.44^{c}$ \\
\hline 49 & $44.44 \pm 5.56^{a}$ & $37.50 \pm 4.17^{\mathrm{ab}}$ & $50.00 \pm 9.62^{a}$ & $33.33 \pm 0.00^{b}$ \\
\hline 63 & $18.18 \pm 0.00^{\mathrm{a}}$ & $18.18 \pm 0.00^{\mathrm{a}}$ & $22.73 \pm 4.44 b^{b}$ & $27.27 \pm 9.09^{a}$ \\
\hline
\end{tabular}

superscripts across a row indicate significant difference between the means of the different groups $(\mathrm{p} \leq 0.05)$. 
Table 4. Mean serum very low density lipoprotein cholesterol concentration $(\mathrm{mg} / \mathrm{dl})$ of albino rats given graded doses of whole quail egg per kilogram body weight $( \pm$ SEM $)$

\begin{tabular}{|c|c|c|c|c|}
\hline \multirow{3}{*}{ Days } & \multicolumn{4}{|c|}{ Means \pm SEM } \\
\hline & Group A & Group B & Group C & Group D \\
\hline & (Control) & $(0.25 \mathrm{mg} / \mathrm{kg})$ & $(0.5 \mathrm{mg} / \mathrm{kg})$ & $(1.0 \mathrm{mg} / \mathrm{kg})$ \\
\hline 7 & $17.78 \pm 6.79^{a}$ & $21.11 \pm 3.33^{a}$ & $17.78 \pm 2.57^{a}$ & $14.44 \pm 1.11^{\mathrm{a}}$ \\
\hline 21 & $15.00 \pm 0.00^{\mathrm{a}}$ & $17.50 \pm 2.50^{\mathrm{ab}}$ & $20.00 \pm 2.89^{b}$ & $10.00 \pm 0.00^{c}$ \\
\hline 35 & $13.33 \pm 1.33^{a}$ & $16.00 \pm 2.83^{\mathrm{ab}}$ & $18.67 \pm 2.67^{b}$ & $8.00 \pm 1.63^{c}$ \\
\hline 49 & $10.67 \pm 2.67^{a}$ & $21.00 \pm 1.92^{b}$ & $20.00 \pm 2.31^{b}$ & $19.00 \pm 1.00^{\mathrm{b}}$ \\
\hline 63 & $4.44 \pm 0.00^{\mathrm{a}}$ & $11.11 \pm 1.28^{\mathrm{b}}$ & $10.00 \pm 2.13^{\mathrm{bc}}$ & $7.78 \pm 1.11^{\mathrm{c}}$ \\
\hline
\end{tabular}

Table 5. Mean serum triglyceride concentration $(\mathrm{mg} / \mathrm{dl})$ of albino rats given graded doses of whole quail egg per kilogram body weight $( \pm$ SEM)

\begin{tabular}{ccccc}
\hline & \multicolumn{4}{c}{ Means \pm SE } \\
\cline { 2 - 5 } Days & $\begin{array}{c}\text { Group A } \\
(\text { Control })\end{array}$ & $\begin{array}{c}\text { Group B } \\
(0.25 \mathrm{mg} / \mathrm{kg})\end{array}$ & $\begin{array}{c}\text { Group C } \\
(0.5 \mathrm{mg} / \mathrm{kg})\end{array}$ & $\begin{array}{c}\text { Group D } \\
(1.0 \mathrm{mg} / \mathrm{kg})\end{array}$ \\
\hline 7 & $88.89 \pm 33.94^{\mathrm{b}}$ & $105.56 \pm 16.67^{\mathrm{a}}$ & $88.89 \pm 12.83^{\mathrm{ab}}$ & $72.23 \pm 5.56^{\mathrm{b}}$ \\
21 & $75.00 \pm 0.00^{\mathrm{a}}$ & $87.50 \pm 12.50^{\mathrm{ab}}$ & $100.00 \pm 14.43^{\mathrm{b}}$ & $50.00 \pm 0.00^{\mathrm{c}}$ \\
35 & $66.67 \pm 6.6^{\mathrm{a}}$ & $80.00 \pm 14.14^{\mathrm{bb}}$ & $93.33 \pm 13.33^{\mathrm{b}}$ & $40.00 \pm 8.17^{\mathrm{c}}$ \\
49 & $53.33 \pm 13.33^{\mathrm{a}}$ & $105.00 \pm 9.57^{\mathrm{b}}$ & $100.00 \pm 11.55^{\mathrm{b}}$ & $95.00 \pm 5.00^{\mathrm{b}}$ \\
\hline 3 & $22.22 \pm 0.00^{\mathrm{a}}$ & $55.56 \pm 6.42^{\mathrm{b}}$ & $50.00 \pm 10.64^{\mathrm{bc}}$ & $38.89 \pm 5.56^{\mathrm{c}}$ \\
\hline abc superscripts across a row indicate significant difference between the means of the different groups $(\mathrm{p} \leq 0.05)$. &
\end{tabular}

Table 6. Mean cauda epididymal sperm reserves of albino rats given graded doses of whole quail egg per kilogram body weight $( \pm$ SEM $)$

\begin{tabular}{ccccc}
\hline \multirow{2}{*}{ Days } & \multicolumn{4}{c}{ Means \pm SE } \\
\cline { 2 - 5 } & Group A & Group B & Group C & Group D \\
& $($ Control $)$ & $(0.25 \mathrm{mg} / \mathrm{kg})$ & $39.5 \mathrm{mg} / \mathrm{kg})$ & $6.1 \mathrm{mg} / \mathrm{kg})$ \\
\hline \multirow{2}{*}{63} & $314000000^{\mathrm{a}}$ & $332000000^{\mathrm{ab}}$ & $39000000^{\mathrm{b}}$ & $625000000^{\mathrm{c}}$ \\
& \pm 8185350 & \pm 29143320 & \pm 53436360 & \pm 43247350 \\
\hline
\end{tabular}

$\overline{\mathrm{abc}}$ superscripts across a row indicate significant difference between the means of the different groups $(\mathrm{p} \leq 0.05)$.

that of the control group (Table 5). However, on days 49 and 63 of dosing the mean serum triglyceride concentration of all the treatment groups was higher than that of the control group (Table 5). At the end of dosing on day 63, the cauda epididymal sperm reserve of groups $\mathrm{C}$ and $\mathrm{D}$ was significantly higher than that of the control group (Table 6).

Photomicrographs of sections of the testes and liver from rats (Fig. 1-5) in the treatment groups did not show any obvious histopathologic lesions and also did not differ from those of the control group. Thus, they did not show any deviation from the normal testicular and hepatic histomorphology. The photomicrographs of the testes in all the groups showed normal seminiferous tubules lined by stratified epithelium of spermatogenic cells and Sertoli cells (S). Between the basement membranes of the seminiferous tubules are thin vacular loose connective tissue which holds the Leydig cells in all the groups. Late spermatids (Ls), early spermatids (Es), primary spermatids (Ps), spermatogonium $(\mathrm{Sp})$, the lumen of a seminiferous tubule (L), interstitial cells were also shown. The liver showed hepatic lobules with normal hepatocytes arranged in chords (arrow) around the central veins $(\mathrm{V})$, radiating towards the portal areas which showed the hepatic artery (HA), hepatic vein (HV) and bile $\operatorname{duct}(\mathrm{B})$.

\section{Discussion}

The results of the hereby study revealed that oral administration of raw whole Japanese quail eggs to rats produced a hypocholesterolemic effect by the end of days 35 and 49 at the highest dose. However, the cholesterol level recorded for the different treatment groups fell within the

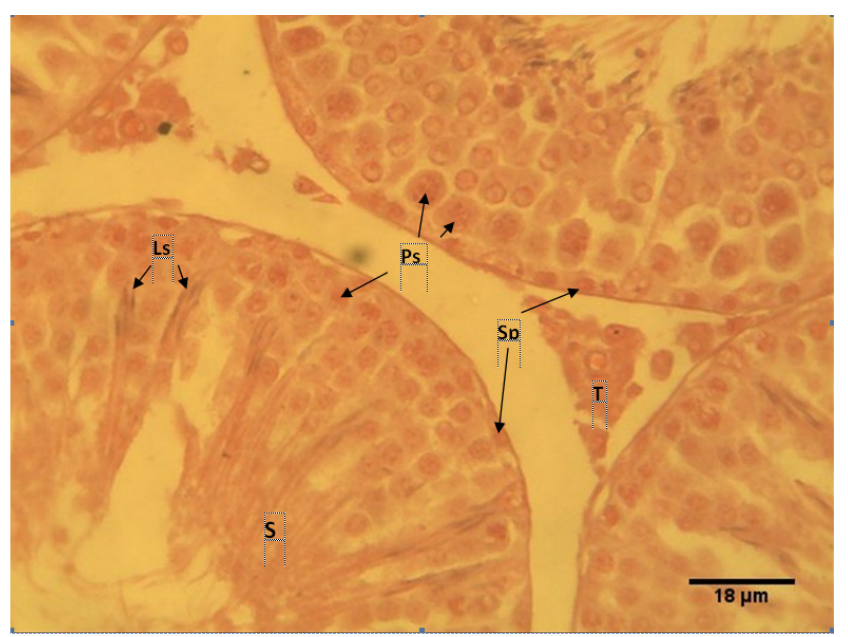

Fig. 1. Histological appearance of testis of rat given $0.25 \mathrm{mg} / \mathrm{kg}$ body weight of quail egg orally for 63 days, showing no obvious lesions. Note active seminiferous tubules (S) bearing spermatogonium (Sp), primary spermatids (Ps), late spermatids (Ls) and interstitium (T); Hematoxylin \& Eosin $(\mathrm{H} \& \mathrm{E}) \times 400$

minimum and maximum cholesterol reference values reported by Ihedioha et al. (2013) for rats in the same geographic location. Oral administration of raw whole Japanese quail eggs to rats at the doses of $0.25,0.5$ and 1.0 $\mathrm{ml} / \mathrm{kg}$ body weight had varied effects on the different density fractions of serum lipoprotein cholesterol. At the dose of $1.0 \mathrm{ml} / \mathrm{kg}$ body weight there was an initial reducing 


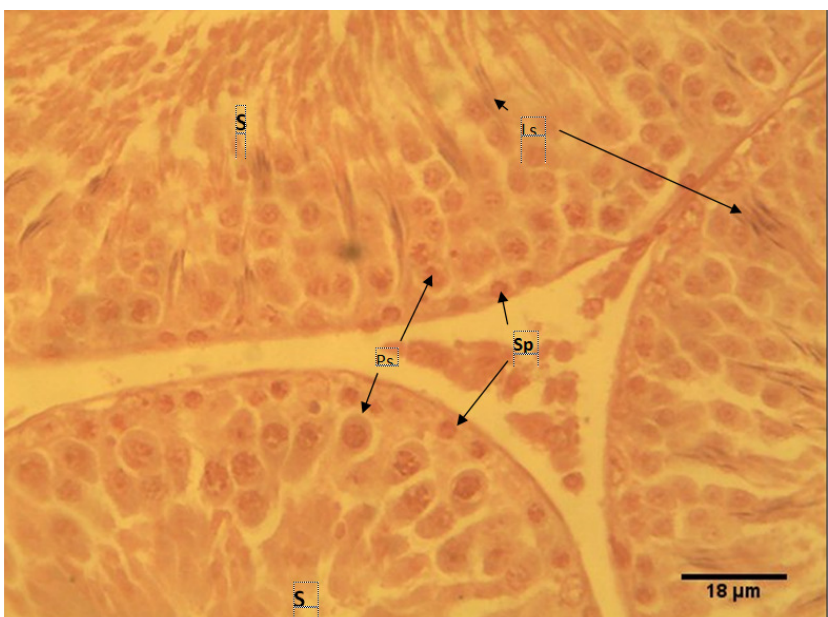

Fig. 2. Histological appearance of testis of rat given $0.5 \mathrm{mg} / \mathrm{kg}$ body weight of quail egg orally for 63 days, showing no obvious lesions. Note active seminiferous tubules ( $S$ ) bearing spermatogonium (Sp), primary spermatids (Ps), late spermatids (Ls); Hematoxylin \& Eosin $(\mathrm{H} \& \mathrm{E}) \times 400$

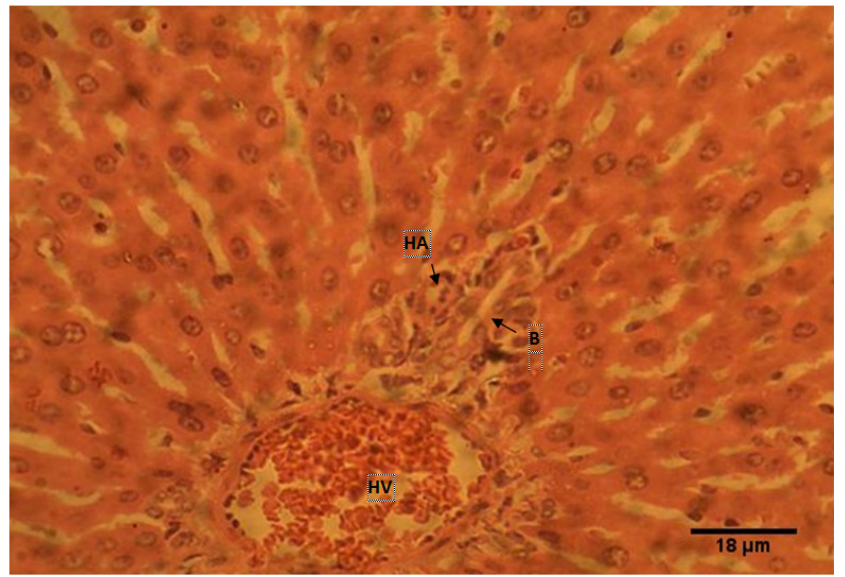

Fig. 4. Histological appearance of liver of rat given $0.25 \mathrm{mg} / \mathrm{kg}$ body weight of quail egg orally for 63 days, showing no obvious lesions. Note the hepatic lobules with normal hepatocytes arranged in chords radiating towards the portal areas which show the hepatic artery (HA), hepatic vein (HV) and bile duct (B); Hematoxylin \& Eosin $(\mathrm{H} \& \mathrm{E}) \times 400$

effect on the vLDL cholesterol, but continued administration produced a net increase. There was a net reducing effect on the serum LDL cholesterol unlike the serum HDL cholesterol that was not consistent. The values of the serum vLDL, LDL, HDL cholesterol and triglyceride concentrations observed in this study were all below the upper limit for the reference values reported by Ihedioha $e t$ al. (2013) for rats in the same geographic location. The increase in serum vLDL cholesterol and triglyceride concentration observed in the study may suggest that consumption of quail eggs may predispose to cardiovascular pathologies, a finding supported by the report of Bragagnalo and Rodriguez-Amaya (2003).

The absence of any obvious pathological lesions in the histomorphology of the testes of rats post administration with $0.25,0.5$ and $1.0 \mathrm{ml} / \mathrm{kg}$ body weight of whole Japanese quail egg for 63 days suggests that whole quail egg may not

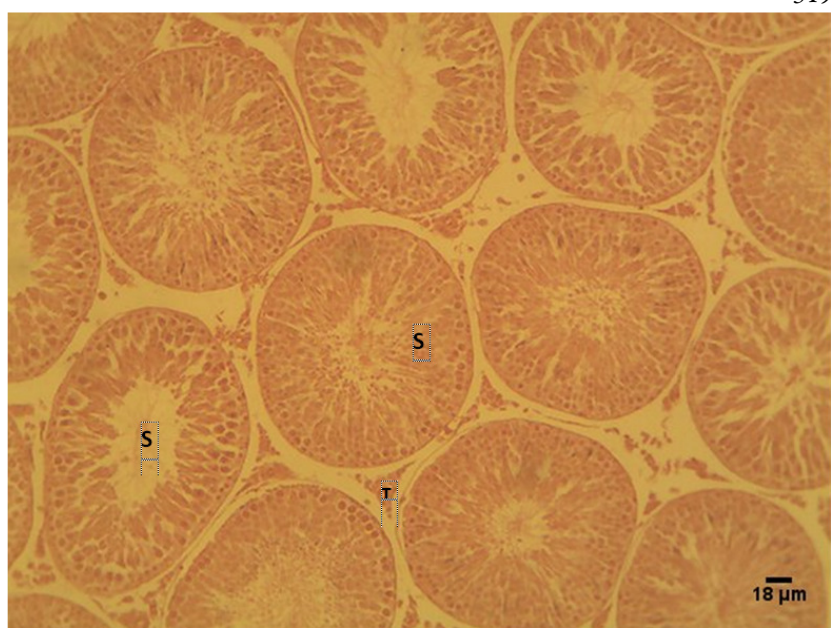

Fig. 3. Histological appearance of testis of rat given $0.5 \mathrm{mg} / \mathrm{kg}$ body weight of quail egg orally for 63 days, showing no obvious lesions. Note active seminiferous tubules $(S)$ and interstitium (T); Hematoxylin \& Eosin $(\mathrm{H} \& \mathrm{E}) \times 100$

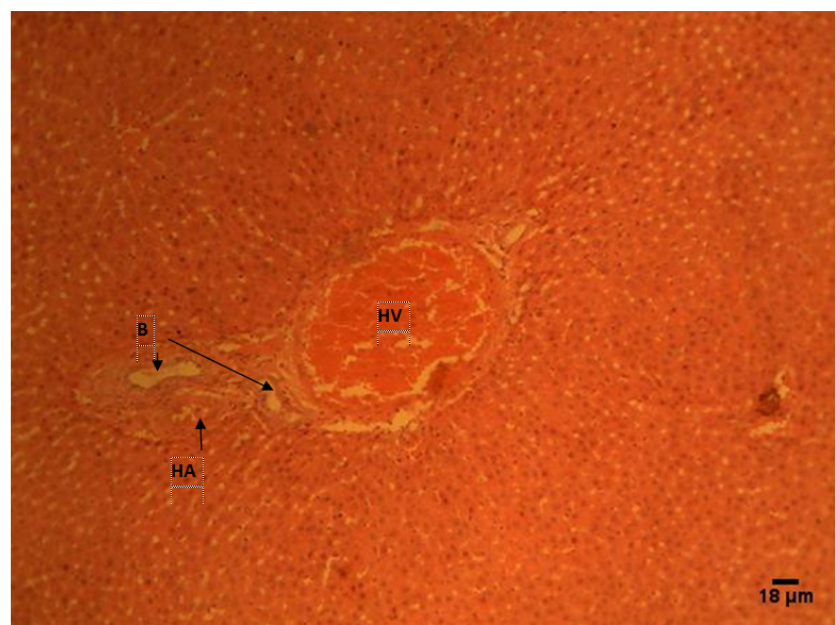

Fig. 5. Histological appearance of liver of rat given $0.5 \mathrm{mg} / \mathrm{kg}$ body weight of quail egg orally for 63 days, showing no obvious lesions. Note the hepatic artery (HA), hepatic vein (HV) and bile duct (B); Hematoxylin \& Eosin $(\mathrm{H} \& \mathrm{E}) \times 100$

adversely affect the histomorphology of the testes. However, the finding of significantly increased CESR at the dosing regimen of 0.5 and $1.0 \mathrm{ml} / \mathrm{kg}$ at the end of 63 days shows that whole quail egg may potentiate the spermatogenic activities of the testes. Increase in sperm number and a normal testicular histology are positive indices of fertility (Al-Sa'aidi et al., 2009; Etuk and Muhammad, 2009). It is possible that the dose-dependent increase in the CESR could be due to enhanced steroidogenesis (Pakarainen et al., 2005) through the additional progesterone and testosterone supplied by the whole quail eggs (Tunsaringkarn et al., 2013) through the delta-5 pathway (Jockenhovel and Swerdloff, 2000) since there was no disruption of the histomorphology of the testes. This is further collaborating by the observed hypocholesterolemic effect of the whole quail egg, especially at the high dose regimen on days 35 and 49. Since cholesterol is a precursor of sex steroids ( $\mathrm{Hu}$ et al., 
320

2010), higher CESR values should not be expected of this group that had lower cholesterol level.

The role of the liver in biotransformation of xenobiotics is of great importance (Haschek et al., 2009). In adittion, the histomorphologic evaluation of the liver could reveal alterations in this organ and the overall metabolic activities of the individual which may not be obvious following only clinical biochemical evaluation (Haschek et al., 2009; Smith et al., 2013). The absence of obvious histopathological lesions in liver of rat dosed with raw whole quail eggs in this study suggests that raw quail egg consumption may not directly affect the histomorphology of the liver.

\section{Conclusions}

Consumption of whole quail egg may enhance fertility of males attributed to the increase in cauda epididymal sperm reserve. In addition prolonged consumption may predispose to cardiovascular diseases due to the increases in serum vLDL cholesterol and triglyceride.

\section{References}

Albers JJ, Warnick GR, Cheung MC (1978). Quantification of high density lipoproteins.Lipids 13:926-932.

Allain CC, Poon LS, Chan CS, Richmond W, Fu PU (1974) Enzymatic determination of total cholesterol. Clinical Chemistry 20:470-475.

Al-Sảaidi JAA, Al-Khuzai ALD, Al-Zobaydi NFH (2009). Effect of alcoholic extract of Nigella sativa on fertility in male rats. Iraqi Journal of Veterinary Science 23:123-128.

Amann RP, Almquist JO (1961). Reproductive capacity of dairy bulls. 1. Techniques for direct measurement of gonadal and extra-gonadal sperm reserves.Journal of Dairy Science 44:1537-1545.

Awad A, Khali SR, Abd-Elhakim YM (2015). Molecular phylogeny of some avian species using Cytochrome b gene sequence analysis. Iranian Journal of Veterinary Research 16:218-222.

AzizZ, CyriacS, Beena V, Philomina PT (2012). Comparison of cholesterol content in chicken, duck and quail egogs. Journal of Veterinary Animal Science 43:6466.

Bragagnalo N, Rodriguez-Amaya DB (2003). Comparison of the cholesterol content of Brazilian chicken and quail eggs. Journal of Food Composition and Analysis 16:147-153.

Bucolo G, David H (1973). Quantitative determination of serum triglycerides by use of enzymes. Clinical Chemistry 19:476482.

Campos MS, Hernández RP, Guerrero LC, Ruelas AC, Tintoré SG, Ancona DB (2013). Physicochemical and functional properties of dehydrated Japanese quail (Coturnix japonica) egg white. Food Nutrition Science 4:289-298.

Etuk EU, Muhammad AA (2009). Fertility enhancing effects of aqueous stem bark extract of Lophira lanceolata in male Sprague Dawley rats. International Journal of Plant Physiology and Biochemistry 1:14.
Friedewald WT, Levy RI, Fredrickson DS (1972). Estimation of the concentration of low density lipoprotein cholesterol in plasma, without use of the preparative ultracentrifuge. Clinical Chemistry 18:499-502.

Haschek WM, Rousseaux CG, Wallig MA (2009). Fundamentals of toxicologic pathology. Academic Press.

Hu J, Zhang Z, Shen WJ, Azhar S (2010) Cellular cholesterol delivery, intracellular processing and utilization for biosynthesis of steroid hormones. Nutrition Metabolism 7:472.

Igwebuike UM,EzeUU (2010) Morphology of the ceca of the African pied crow (Corvus albus). Animal Research International 7:1121-1124.

Ihedioha JI, Noel-Uneke OA, Ihedioha TE (2013). Reference values for the serum lipid profile of albino rats (Rattus norvegicus) of varied ages and sexes. Comparative Clinical Pathology 22:93-99.

Jalaludeen A, Churchil RR (2006). Duck eggs and their nutritive value. Poultryline 10:35-39.

Jockenhovel F, Swerdloff RS (2000). Alterations in the steroidogenic capacity of Leydig cells in cryptorchid testis. In: The cryptorchid testis. CRC Press Inc, Florida, USA.

Kovacs-Nolan J, Philips M, Mine Y (2005). Advances in the value of eggs and egy components for human health. Journal of Agriculture and Food Chemistry 53:8421-8431.

National Veterinary Research Institute (NVRI) (1994). Farmer training on quail production and health management.

Onyewuchi UU, Offor IR, Okoli CF (2013). Profitability of quail bird and egg production in Imo State. Nigerian Journal of Agriculture and Food Environment 9:40-44.

Pakarainen T, Zhang F, Makela S, Poutanen M, Huhtamiemi I (2005). Testosterone replacement therapy induces spermatogenesis and partially restoresfertility in luteinizing hormone receptor knockout mice. Endocrinology 146:596-606.

Sinanoglou VJ, Strati IF, Miniadis-Meimaroglou S (2011). Lipid, fatty acid and carotenoidcontent of edible egg yolks from avian species: A comparative study. Food Chemistry 124:971-977.

Smith GS, Walter GL, Walker RM (2013). Clinical pathology in nonclinical toxicology testing. In: Haschek WM, Rousseaux CG (Eds). Haschek and Rousseaux's Handbook of Toxicologic Pathology $3^{\text {rd }} \mathrm{ed}$, Elsevier Incpp 563-590.

StoneSH (1954). Method for obtainingvenous blood from the orbital sinus of a rat or mouse. Science 119:100-102.

Tolik D, Polawska E, Charuta A, Nowaczewski S, Cooper R (2014). Characteristics of egg parts, chemical composition and nutritive value of Japanesequail egg-a review. Folia Biology 62:287-292.

Tunsaringkarn T, Tungjaroenchai W, Siriwong W (2013). Nutrient benefits of quail (Coturnix coturnix japonica) eggs. International Journal of Science Research Publication 3:1-8.

Warnick GR, Knopp RH, Fitzpatrick V, Branson L (1990). Estimatinglowdensity lipoprotein cholesterol by the Friedewald equation is adequate for classifying patients on the basis of nationality recommended cut points. Clinical Chemistry 36:15-19. 